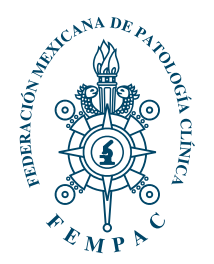

\title{
ReSÚMENES
}

\section{Resúmenes de trabajos libres del XXV Congreso de la Asociación Latinoamericana de Patología Clínica y Medicina de Laboratorio 2021}

\author{
Abstracts of free papers of the XXV Congress of the Latin American \\ Association of Clinical Pathology and Laboratory Medicine 2021
}

\author{
Niveles de 25 hidroxivitamina D en Chile \\ durante la pandemia por SARS-CoV-2 \\ 25-hydroxy-vitamin D levels in Chile \\ during the SARS-CoV-2 pandemic \\ Rodríguez David,* Vera Francisco,* \\ González César, ${ }^{\ddagger}$ Parada Jaqueline, ${ }^{\ddagger}$ \\ Quiroga Teresita* \\ * Departamento de Laboratorios Clínicos, \\ Facultad de Medicina, Pontificia \\ Universidad Católica de Chile, Chile. \\ * Laboratorio de Bioquímica, Servicio de Laboratorios \\ Clínicos Red de Salud UC-CHRISTUS. Chile.
}

RESUMEN. Introducción: La vitamina D es un compuesto esteroidal que se sintetiza a partir del 7-dehidrocolesterol en la piel cuando se expone a la luz solar o se obtiene a través de alimentos o suplementos. Para ejercer su acción biológica primero es hidroxilada en el hígado (25-OH-vitamina D) y luego a su principal forma activa en el riñón $(1,25$ $\mathrm{OH}$-vitamina D). En circulación, la 25-OH-vitamina $D$ es la principal forma circulante de vitamina $D$ y es el mejor indicador de su nivel endógeno. Sus niveles disminuyen, entre otros factores, por exposición insuficiente a la luz solar y una dieta con poco aporte de vitamina $D$, por lo que se plantea como hipótesis que, debido a las medidas de confinamiento en Chile derivadas de la pandemia por SARS-CoV-2, sus niveles poblacionales podrían disminuir. Objetivo: Comparar los niveles séricos de 25-OH-vitamina D en una muestra de pacientes prepandemia (2019) y una muestra de pacientes durante la pandemia
(2020). Material y métodos: Se analizaron 7,423 resultados de determinaciones de $25-\mathrm{OH}$-vitamina D del año 2019 y 8,456 de 2020, seleccionadas mediante muestreo aleatorio simple, realizadas por electroquimioluminiscencia en el Laboratorio de Bioquímica de la Red de Salud UC-CHRISTUS y se compararon las medias con la prueba t de Student. Resultados: La media de niveles de 25-OH-vitamina D de la muestra del año 2019 fue de $26.28 \mathrm{ng} / \mathrm{mL}$ (IC95\% 25.98-26.57), mientras que la del año 2020 fue de $24.55 \mathrm{ng} / \mathrm{mL}$ (IC95\% 24.29-24.80 ng/mL) siendo significativamente diferentes $(p<0.0001)$. Conclusiones: Los niveles de 25-OH-vitamina D de la muestra del año 2020 fueron en promedio 1.73 $\mathrm{ng} / \mathrm{mL}$ menores que los del año 2019, diferencia que podría no ser clínicamente relevante, pero al final explicarse por la interferencia de las medidas de confinamiento poblacional en el metabolismo de la vitamina D. Sin embargo, se debe tener en cuenta que las muestras analizadas son independientes (sin cuantificación prepandemia y durante la pandemia del mismo paciente) y podrían no representar el comportamiento poblacional.

Palabras clave: Vitamina D, SARS-CoV-2, pandemia.

ABSTRACT. Introduction: Vitamin $D$ is a steroidal compound that is synthesized from 7-dehydrocholesterol in the skin when exposed to sunlight or obtained through food or supplements. To exert its biological action, it is hydroxylated first in the liver (25-OH-vitamin $\mathrm{D})$ and then to its main

Citar como: Resúmenes de trabajos libres del XXV Congreso de la Asociación Latinoamericana de Patología Clínica y Medicina de Laboratorio 2021. Rev Mex Patol Clin Med Lab. 2021; 68 (2): 90-92. https://dx.doi.org/10.35366/103345 
active form in the kidney (1,25 OH-vitamin D). In circulation, $25-\mathrm{OH}$-vitamin $\mathrm{D}$ is the main circulating form of vitamin $\mathrm{D}$ and is the best indicator of its endogenous level. Its levels decrease, among other factors, due to insufficient exposure to sunlight and a diet with little vitamin $D$ intake, which is why it is hypothesized that, due to the confinement actions in Chile derived from the SARS-CoV-2 pandemic, the levels could decrease. Objective: To compare the serum levels of 25-OH-vitamin D in a sample of pre-pandemic patients (2019) and a sample of patients during the pandemic (2020). Material and methods: 7,423 results of determinations of 25-OH-vitamin D of the year 2019 and 8,456 of 2020, selected by simple random sampling, carried out by electrochemiluminescence in the Laboratory of Biochemistry of the UC-CHRISTUS Health Network were analyzed and compared means by Student's $t$ test. Results: The mean 25-OH-vitamin D levels of the 2019 sample was $26.28 \mathrm{ng} /$ $\mathrm{mL}$ (95\% Cl 25.98-26.57) while that of 2020 was $24.55 \mathrm{ng} / \mathrm{mL}$ (95\% Cl 24.29-24.80 $\mathrm{ng} / \mathrm{mL}$ ) being significantly different ( $p<$ 0.0001). Conclusions: The $25 \mathrm{OH}$-vitamin D levels of the 2020 sample were on average $1.73 \mathrm{ng} / \mathrm{mL}$ lower than those of 2019, a difference that may not be clinically relevant but eventually be explained by the interference of the population confinement actions in the metabolism of vitamin D. However, it must be considered that the samples analyzed are independent (without pre-pandemic quantification and during the pandemic of the same patient) and may not represent population behavior.

Keywords: Vitamin D, SARS-CoV-2, pandemic.

Correspondencia: David Rodríguez

Laboratorio de Trombosis y Hemostasia, Av. Portugal 61

2do piso, Santiago Centro, Santiago, Chile.

E-mail: drodriguez@ucchristus.cl

\section{Utilidad de la espectroscopia infrarroja} (FIIR) en el análisis de cálculos urinarios respecto a métodos tradicionales

Usefulness of infrared spectroscopy

(FTIR) in the analysis of urinary calculi compared to traditional methods

Rodríguez David,* Bravo Juan, ${ }^{\ddagger}$ Quiroga Teresita,*

Silva Patricio, ${ }^{\S}$ Astroza Gastón ${ }^{\ddagger}$

* Departamento de Laboratorios Clínicos, Facultad de

Medicina, Pontificia Universidad Católica de Chile. Chile.

‡ Departamento de Urología, Facultad de Medicina,

Pontificia Universidad Católica de Chile. Chile.

$\S$ Laboratorio de Bioquímica, Servicio de Laboratorios

Clínicos, Red de Salud UC-CHRISTUS. Chile.

RESUMEN. Introducción: La urolitiasis es una patología cuya prevalencia está aumentando, quizá debido a mayor incidencia de enfermedades crónico-degenerativas. La pérdida de la fun- ción renal y las infecciones son consecuencias potencialmente graves, por lo que se recomienda el análisis de los cálculos para prevenir la recurrencia basada en los componentes para reducir la morbilidad. Se recomienda infrarrojo por transformación de Fourier (FTIR) como método de referencia para el análisis de cálculos debido a su especificidad y capacidad de detección relativa (semicuantitativa) de múltiples compuestos en una misma muestra, y se consideran obsoletas las baterías químicas húmedas $(\mathrm{BQH})$. Objetivo: Determinar concordancia entre metodologías y rendimiento de FTIR. Material y métodos: Se analizaron muestras clínicas de cálculos urinarios previamente con $\mathrm{BQH}$ en el Laboratorio de Bioquímica, Red de Salud UC-CHRISTUS, con resultado contenido en el sistema de información del laboratorio (SIL) (mayo-diciembre 2019) con muestra suficiente para analizar mediante FTIR. Para describir y analizar los resultados de todos los exámenes de rutina realizados desde la implementación de FTIR (septiembre 2019) hasta la actualidad (agosto 2020) se accedió al SIL. Resultados: Se compararon 56 muestras por ambas metodologías, 51.8\% (29/56) de los ensayos fueron concordantes, en $42.8 \%$ (24/56) FTIR reveló más cantidad de compuestos, y en $5.3 \%$ (3/56) las $\mathrm{BQH}$ mostraron más que FTIR; de forma global se detectaron 172 compuestos (no necesariamente diferentes), $68.9 \%$ por ambos métodos (122/172), 27.3\% (47/172), además por FTIR y $1.7 \%$ (3/172) por BQH y no por FTIR. Se analizaron 306 muestras de pacientes mediante FTIR, $61.1 \%$ del sexo masculino, edad promedio $49.2 \pm 15.7$ años, $45.8 \%$ con $\geq$ un fragmento, con longitud promedio mayor de $4.8 \pm 2.5 \mathrm{~mm}$, conformado por tres, dos y un compuestos en $51.6 \%, 46.4 \%$ y $1.9 \%$ de las muestras, respectivamente, encontrándose 19 distintos tipos, de los cuales los más frecuentes fueron el oxalato de calcio monohidratado (31.54\%), ácido úrico (14.1\%), carbonato de apatita $(10.86 \%)$, oxalato de calcio dihidratado (9.82\%), proteína $(6.68 \%)$ y estruvita (4.84\%). Conclusiones: FTIR demuestra un rendimiento superior a $\mathrm{BQH}$ debido a la capacidad de los compuestos para la detección y estimación de la proporción relativa de los componentes en una muestra, lo que permitiría un mejor manejo clínico y la prevención de una eventual recurrencia.

Palabras clave: Urolitiasis, espectroscopia infrarroja, cálculo urinario.

ABSTRACT. Introduction: Urolithiasis is a pathology whose prevalence is increasing, probably due to a higher incidence of chronic degenerative diseases. Loss of kidney function and infections are potentially serious consequences, so analysis of stones to prevent recurrence based on components is recommended to reduce morbidity. Infrared spectroscopy (FTIR) is recommended as a reference method for stone analysis due to its specificity and relative (semi-quantitative) detection capacity of multiple compounds in the same sample, and wet chemical batteries $(B Q H)$ are considered obsolete. Objective: 
To determine concordance between methodologies and FTIR performance. Material and methods: Clinical samples of urinary stones were previously analyzed with $\mathrm{BQH}$ in the Biochemistry Laboratory, UC-CHRISTUS Health Network, with results contained in the Laboratory Information System (LIS) (May-December 2019) with sufficient remain sample to analyze by FTIR. To describe and analyze the results of all routine examinations performed since the implementation of FTIR (September 2019) to the present (August 2020), the LIS was accessed. Results: 56 samples were compared by both methodologies, $51.8 \%$ (29/56) trials were concordant, in $42.8 \%$ (24/56) FTIR reported a greater number of compounds, and in 5.3\% (3/56) BQH reported more than FTIR ; globally, 172 compounds (not necessarily different) were detected, $68.9 \%$ by both methods (122/172), 27.3\% (47/172) additionally by FTIR and $1.7 \%$ (3/172) by BQH and not by FTIR. 306 patient samples were analyzed by FTIR, $61.1 \%$ male, average age $49.2 \pm 15.7$ years, $45.8 \%$ with $\geq 1$ fragments, with an mean length of the largest of $4.8 \pm 2.5 \mathrm{~mm}$, made up of 3,2 and 1 compounds in $51.6 \%, 46.4 \%$ and $1.9 \%$ of the samples respectively, finding 19 different types, of which the most frequent were calcium oxalate monohydrate (31.54\%), uric acid (14.1\%), apatite carbonate (10.86\%), oxalate of calcium dihydrate (9.82\%), protein (6.68\%) and struvite (4.84\%). Conclusions: FTIR shows superior performance to $B Q H$, due to the ability of compounds that can detect and estimate the relative proportion of the components in a sample, which would allow a better clinical management and eventual prevention of recurrence.

Keywords: Urolithiasis, infrared spectroscopy, urinary stone.

Correspondencia: David Rodríguez

Laboratorio de Trombosis y Hemostasia, Av. Portugal 61 2do piso, Santiago Centro, Santiago, Chile.

E-mail: drodriguez@ucchristus.cl 